\title{
Silver Nanoweapons: A novel Tool against Multidrug Resistant Bacteria
}

\author{
Hussam H. Arafat ${ }^{*}$, Mohammed H. El-Sayed ${ }^{1}$ and A. Askora ${ }^{2}$ \\ ${ }^{1}$ Department of Biology, Faculty of Science and Arts, Northern Border University, Rafha, KSA. \\ ${ }^{2}$ Department of Botany, Faculty of Science, Zagazig University, Zagazig City- 44519, Egypt. \\ *Department of Botany \& Microbiology, Faculty of Science, Minia University, Minia City- 61519, Egypt.
}

\author{
http://dx.doi.org/10.13005/bbra/2009
}

(Received: 13 March 2015; accepted: 30 March 2015)

\begin{abstract}
Antibacterial activities of Ag-NPs have received much attention due to their effective killing and cost-effectiveness. Biosynthesis is an attractive and eco-friendly method to produce silver nanoparticles (Ag-NPs). Ag-NPs are considered a promising tool to overcome the emergence of multi-drug resistant bacteria. In this study, bio-synthesis of Ag-NPs was attempted using plant extracts of peppermint. Characterization of Ag-NPs was achieved by UV-visible spectrophotometer and TEM. Monodispersed Ag-NPs were obtained with different sizes ranged from 6 to $88 \mathrm{~nm}$. Antibacterial activities of Ag-NPs against pathogenic bacteria were evaluated using disc diffusion method. Our results indicated that Gram positive bacteria were more susceptible than Gram negative. The current study offers a cost-effective and eco-friendly method for biosynthesis of potent bactericidal Ag-NPs and their use against human pathogenic bacteria.
\end{abstract}

Keywords: Silver nanoparticles, Pathogenic bacteria, Green synthesis, Silver nanoweapons.

Multidrug resistant (MDR) bacteria continue to threat human beings. Infections caused by MDR bacteria lead to long periods of hospitalization with low chance of treatment ${ }^{1}$. Widely use of antibiotics forces bacteria to resist antibiotics via several mechanisms ${ }^{2}$. Therefore, searching for alternative approaches other than antibiotics is a focus of research ${ }^{3}$. Nanoparticles (NPs) particularly silver nanoparticles (Ag-NPs) open new avenues to develop novel antibacterial drugs $^{4}$. Several reports investigated the use AgNPs against a wide array of bacteria. For example, low concentrations of Ag-NPs were found to be more effective against E. coli ${ }^{5}$, S. aureus ${ }^{4,6}$, Pseudomonas aeruginosa $^{7}$, Vibrio cholerae ${ }^{8}$ and Bacillus subtilis ${ }^{9}$. Moreover, Ag-NPs were reported to be effective against ampicillin-resistant Escherichia coli, erythromycin-resistant

\footnotetext{
* To whom all correspondence should be addressed. Tel.: 00966566357814;

E-mail: Hussamhassan77@yahoo.co.uk, hussam.arafat@nbu.edu.sa
}

Strepococcus pyogenes, methicillin- resistant Staphylococcus aureus (MRSA) and vancomycinresistant Staphylococcus aureus (VRSA) ${ }^{5,10-12}$. AgNPs also have antimicrobial effects against fungi ${ }^{13}$, ${ }^{14}$ and viruses ${ }^{15}$.

The size and morphology of Ag-NPs are two critical issues that determine the efficiency of antibacterial activity ${ }^{16,17}$. The mechanism of AgNPs action is not clearly defined, however, several mechanisms were proposed. Adsorption of Ag-NPs by bacterial cells leads to loss of membrane permeability and toxicity ${ }^{16,18}$. Ag-NPs were also proposed to exert their activity via reducing DNA replication and interfere with ribosomes ${ }^{19}$. Silvercontaining compounds such as silver nitrates serve as a good source to generate Ag-NPs by reductions assays. For this purpose, several chemical, physical and biological methods were described ${ }^{20}$, ${ }^{21}$. However, the use of biology-based methods is low cost, safe and ecofriendly ${ }^{22,23}$. Of these biological sources, plant extracts are rich with bioreducing agents such as terpenoids, amides, carboxylic acids, proteins, DNA, enzymes, etc ${ }^{24}$. In 
the current study, biosynthesis of Agnanoparticles was achieved by reduction of silver nitrate. Plant extract was used as bio-reducing agent. Peppermint plant was selected for the reduction process on the base of their availability and ease of extraction. Synthesized Ag-NPs were analyzed by UV-visible spectrophotometer, TEM and SEM. In addition, bactericidal activity of AgNPs was tested against two common human pathogenic bacteria from both the Gram-Positive and Gram-Negative bacteria.

\section{MATERIALSANDMETHODS}

\section{Preparation of Plant Extract}

Plant parts of peppermint were rinsed several times with distilled water to remove dusts. $10 \mathrm{~g}$ of the plant were cut into small pieces in two separated $250 \mathrm{~mL}$ Erlenmeyer flasks. $100 \mathrm{ml}$ of distilled water was added to each flask and boiled for 15 minutes. After boiling has been finished, flasks were cooled down at room temperature and their contents dispensed into $50 \mathrm{ml}$ falcon tubes. To remove large particles and cellular debris, tubes were centrifuged at 10,000 rpm for 30 minutes and supernatants were filtered via $0.2 \mu \mathrm{m}$ Millipore filter into new sterile $50 \mathrm{ml}$ tubes. Tubes were kept in the refrigerator for further use.

\section{Biosynthesis of Silver Nanoparticles}

Biosynthesis of Ag-NPs was attempted by mixing an aqueous solution of silver nitrate (1 $\mathrm{mM}$ ) with pre-formed plant extracts. Change in color was observed which refer to Ag-NPs formation. The reaction was performed in dark conditions with two flasks as controls; the first contains aqueous solution of $\mathrm{AgNO}_{3}$ and the second have only the plant extract. Reaction products containing biosynthesized Ag-NPs were centrifuged at low speed (3000 rpm/20 min) to remove unwanted particles. Supernatants were transferred into sterile tubes and centrifuged again at high speed (20,000 rpm/40 min). Pellets were then collected by reconstitution in $100 \mu \mathrm{l}$ deionized water and air dried.

\section{Characterization of Ag-nanoparticles}

To confirm the identity of biosynthesized Ag-NPs, dilutions from each Ag-NPs suspension were prepared and scanned by UV-visible spectrophotometry (Lambda 35 UV-VIS spectrophotometer) at different wavelengths (300-
$720 \mathrm{~nm}$ ). Absorbencies corresponding to each wavelength were recorded. For further characterization, biosynthesized Ag-NPs were sent to Electron Microscopy Unit, Central Laboratory, King Saud University, Riyadh, KSA. Ag-NPs were also analyzed by scanning and transmission electron microscopy to examine their size and shape. The particle size distribution of Ag-NPs was evaluated using Image J 1.45s software.

\section{Antibacterial Activities of Ag-NPs}

To investigate the antibacterial activities of Ag-NPs, a representative one Gram-Positive and one Gram-Negative bacterial strains were spread as a lawn over Muller Hinton Agar plates and allowed to dry at room temperature. Ag-NPs-loaded disks with three different concentrations $(50 \mu \mathrm{g} /$ $\mathrm{ml}, 5 \mu \mathrm{g} / \mathrm{ml}$ and $0.5 \mu \mathrm{g} / \mathrm{ml}$ ) were placed over the agar plates and the plates were kept for incubation at $37^{\circ} \mathrm{C}$ for $24 \mathrm{~h}$. At the end of incubation, inhibition zones formed around the disc were measured. Disks soaked in sterilized distilled water were used as negative controls.

\section{RESULTS}

\section{Biosynthesis of Ag-NPs}

Biosynthesis of Ag-NPs was attempted by mixing an aqueous solution of $\mathrm{AgNO}_{3}$ and extracts of peppermint. Color turned to yellow as compared with the original color (pale green) (Figure 1A). After 1h the color turned to brownish (Figure 1B). Change in color indicating that the bioreduction process occurred and formation of Ag-NPs.

\section{Characterization of Ag-NPs}

Ag-NPs biosynthesized by peppermint extract was characterized by UV-visible spectrophotometry (Figure 2), TEM (Figure 3) and SEM (Figure 4). The sizes of biosynthesized AgNPs are in the range of 6 to $88 \mathrm{~nm}$. As shown in (Figures 3, 4), the absorbance peak of Ag-NPs is at $420 \mathrm{~nm}$ wavelength which is characteristic for silver nanoparticles.

\section{Antimicrobial Activities of Ag-nanoparticles}

Inhibition zones created by Ag-NPsloaded disks were measured and recorded (Table $1)$. The inhibition effect was greater at concentration of $50 \mu \mathrm{g} / \mathrm{ml}$ and decreased gradually at $5 \mu \mathrm{g} / \mathrm{ml}$ and $0.5 \mu \mathrm{g} / \mathrm{ml}$. The bactericidal effect was more effective against Gram positive bacteria 
than Gram negative (Table 1). The inhibition zone for Gram negative bacteria E. coli recorded the largest size of inhibition zone; $5.7 \mathrm{~mm}$ with $50 \mu \mathrm{g} /$ $\mathrm{ml}$ concentration of silver nanoparticles, however, in case of $B$. cereus the inhibition zone was 10.3 $\mathrm{mm}$ at the same concentration.

\section{DISCUSSION}

Historically, silver vessels have long been used to preserve foods and drinks. In recent years, silver is introduced in the field of clinical applications to fight pathogenic bacteria. Although silver metal is able to inhibit microbial growth, its nano-form is more effective. Several chemical, physiological and biological methods were reported to synthesize Ag-NPs. Of these methods, biosynthesis of Ag-NPs using biological techniques is the most common methods. Biological methods secure safe, cost effective, ecofriendly and easy ways of Ag-NPs formation ${ }^{25}$. Extracts from plants, bacteria and fungi can be used to biosynthesize Ag-NPs by reducing silver salts ${ }^{26}$, 27.

Several literatures reported the use of plant extracts in Ag-NPs synthesis. For example, extracts from Musa balbisiana, Azadirachta indica and Ocimum tenuiflorum ${ }^{28}$, Terminalia arjuna ${ }^{29}$ and Clitoria ternatea and Solanum nigrum ${ }^{30}$. In

Table 1. Antibacterial activities of Ag-nanoparticles synthesized from peppermint

\begin{tabular}{ccccc}
\hline \multirow{2}{*}{ Bacterial strains } & \multirow{2}{*}{ Type } & \multicolumn{3}{c}{ Inhibition zone (mm diameter) } \\
& & $50 \mu \mathrm{g} / \mathrm{ml}$ & $5 \mu \mathrm{g} / \mathrm{ml}$ & $0.5 \mu \mathrm{g} / \mathrm{ml}$ \\
\hline \multirow{2}{*}{ Bacillus cereus } & Gram-positive bacteria & 10.3 & 7.5 & 3.8 \\
Escherichia coli & Gram-negative bacteria & 5.7 & 2.8 & 1.5 \\
\hline
\end{tabular}
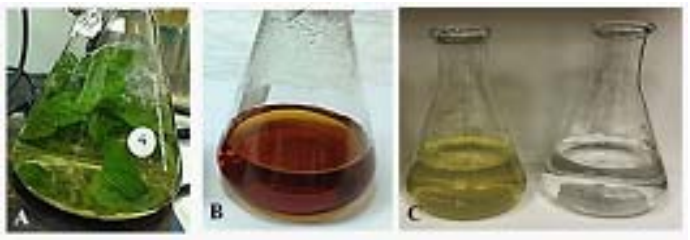

Fig. 1. Biosynthesis of Ag-NPs. A) Preparation of plant extract. B) Color change after 1h. C) Controls: right flask, peppermint's extract and left flask, aqueous solution of Ag-NPs. the current study Ag-NPs of peppermint was synthesized (Figure 1). Selection of this plant is based on its permanent availability and ease of extraction. Plant extract is rich with carbohydrates, proteins, nucleic acids, and other molecules which act as strong bioreducing agents ${ }^{24}$. In in vitro reaction, mixing aqueous solution of silver nitrate with plant extract is associated with color change and Ag-NPs precipitation.

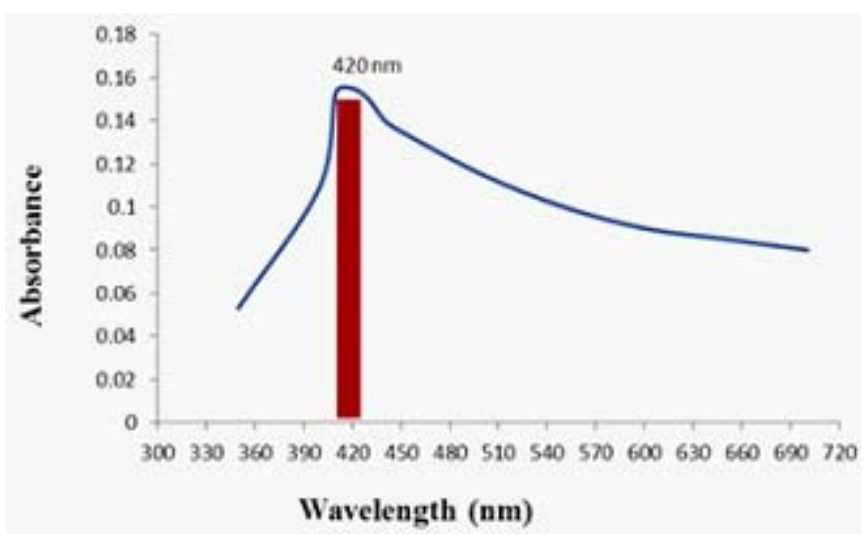

Fig. 2. UV-vis absorption spectrum of Ag-NPs 


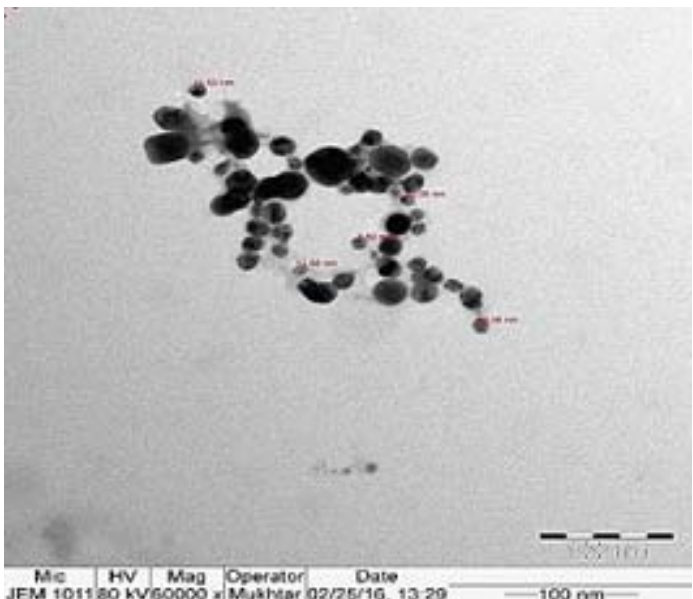

Fig. 3. TEM image of Ag-NPs formed by extract of peppermint

The morphology and resonance properties of Ag-NPs were examined by SEM and UV-visible spectrophotometer, respectively. The size, distribution and stability of Ag-NPs vary with the plant extract or the organism used for the biosynthesis process. Surface plasmon resonance of Ag-NPs reported in previous studies displayed different peak values; E. coli $(400 \mathrm{~nm})^{31}$, Aspergillus niger $(420 \mathrm{~nm})^{32}$, Pisonia grandis (420 $\mathrm{nm})^{33}$, Merrimia tridendata $(440 \mathrm{~nm})^{34}$, Kappaphycus alvarezii $(420 \mathrm{~nm})^{35}$, Citrullus colocynthis $(440 \mathrm{~nm})^{36}$, Allium cepa $(412 \mathrm{~nm})^{37}$. Ag-NPs synthesized in our study have resonance peak values of $420 \mathrm{~nm}$ for peppermint (Figure 2). Ag-NPs obtained in this study are uniform spherical with size ranged from 6 to $88 \mathrm{~nm}$ (Figures 3 and 4). Other investigators synthesized different sizes of Ag-NPs; 30-40 nm by Boswellia ovalifoliolata $^{38} ; 30-50 \mathrm{~nm}$ by Merremia tridendata $^{34}$, Carcia papaya ${ }^{39}$, and Emblica officinalis ${ }^{40}$.

The antibacterial potential of Ag-NPs was assayed using disc diffusion method. Ag-NPs exhibited antibacterial activity against $B$. cereus and E. coli (Table 1). Similar antibacterial activity of Ag-NPs was reported against E. coli, Bacillus cereus and Pseudomonas aeruginosa ${ }^{41}$; Pseudomonas aeruginosa, E. coli, Streptococcus pyrogens, Samonella enteritis ${ }^{36}$; Proteus vulgaris, Vibrio cholera ${ }^{42}$; Staphylococcus aureus, Bacillus subtilis, E. coli and Klebsiella pneumonia ${ }^{43}$,

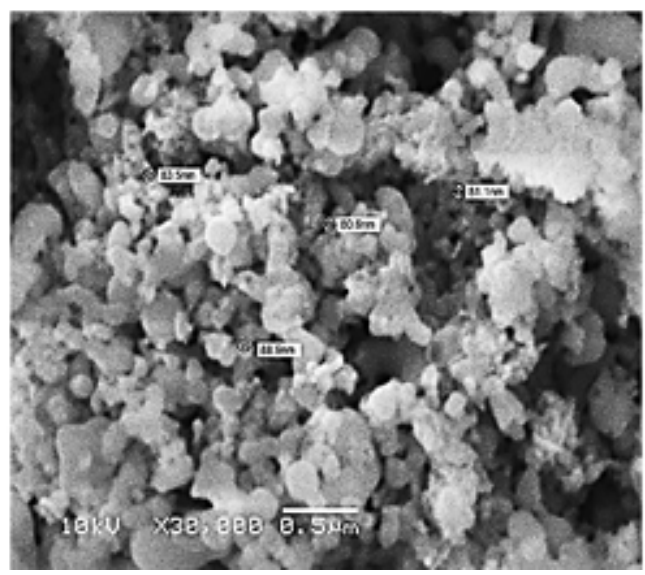

Fig. 4. SEM image of Ag-NPs synthesized by extract of peppermint

Samonella typhi and E. coli ${ }^{44}$; Proteus morgani and Staphylococcus aureus ${ }^{45}$.

Although the bactericidal activities of Ag-NPs vary among bacterial strains, the effect was greater against Gram positive than Gram negative bacteria (Table 1). This is due to the fact that more Ag-NPs accumulate over cell walls of Gram positive bacteria of metals than that of Gram negative bacteria ${ }^{46}$. Another factor that plays a major bactericidal role is the size of Ag-NPs where small size Ag-NPs is more effective than larger one.

The exact mechanism of Ag-NPs action is not clearly defined. However, several hypotheses were proposed to reveal their bactericidal mechanisms. Of these, Gogoi et al, proposed that Ag-NPs have no direct effect on cellular DNA and proteins ${ }^{47}$. Adherence of Ag-NPs to bacterial cell wall results in the formation of pits which in turn lead to permeability loss and cell death ${ }^{4}$. Free radicals generation and release of silver ions by Ag-NPs are possible mechanisms that may lead to cell death ${ }^{6,48}$.

\section{ACKNOWLEDGEMENT}

Hussam H. Arafat, Mohammed H. ElSayed and Askora A., are supported with the research grant No (5/1436/17/8), Deanship of Scientific Research, Northern Border University, Arar, KSA. 


\section{REFERENCES}

1. Webb, G.F., D’Agata, E.M., Magal, P., Ruan S.A. model of 499 antibiotic-resistant bacterial epidemics in hospitals. Proc Nat Acad Sci., 2005; 102: 13343-13348.

2. Tenover, F.C. Mechanisms of antimicrobial resistance in bacteria. Am J Med., 2006; 119: S3-S10.

3. Humberto, H., Lara, V., Ayala-Nunez, N.V., Carmen, L.D., Ixtepan, T. and Cristina, R.P. Bactericidal effect of silver nanoparticles against multidrug-resistant bacteria. W. J. Microbiol. Biotechnol., 2010; 26: 615-621.

4. Sondi, I., Salopek-Sondi, B. Silver nanoparticles as antimicrobial agent: a case study on E. coli as a model for Gram-negative bacteria. J. Colloid Interface Sci., 2004; 275: 177-182.

5. Bonde, S.R., Rathod, D.P., Ingle, A.P., Ade, R.B., Gade, A.K. and Rai, M.K. Murraya koenigiimediated synthesis of silver nanoparticles and its activity against three human pathogenic bacteria. Nanosci Meth., 2012; 1: 25-36.

6. Kim, J.S., Kuk, E., Yu, K., Kim, J.H., Park, S.J., Lee, H.J., Kim, S.H., Park, Y.K., Park, Y.H., Hwang, C.Y., Kim, Y.K., Lee, Y.S., Jeong, D.H., Cho, M.H. Antimicrobial effects of silver nanoparticles. Nanomed., 2007; 3: 95-101.

7. Amirulhusni, J.P., Athirah N., Navindra K.P., Zaini, M., Liew, J.P., Durairaj, R. Antibacterial Effect of Silver Nanoparticles on Multi Drug Resistant Pseudomonas Aeruginosa. Int. J. Med., H., Biomed. Bioeng. Pharm. Eng., 2012; 6(7): 291-294.

8. Morones, J.R., Elechiguerra, J.L., Camacho, A., Holt, K., Kouri, J.B., Ramirez, J.T. and Yacaman, M.J. The bactericidal effect of silver nanoparticles. Nanotech., 2005; 16: 2346-2353.

9. Gong, P., Li, H., He, X., Wang, K., Hu, J., Tan, W., Tan, S. and Zhang, X.Y. Preparation and antibacterial activity of Fe304@Ag nanoparticles. Nanotech., 2007; 18: 604-611.

10. Rai, M., Yadav, A., Gade, A. Silver nanoparticles as a new generation of antimicrobials. Biotechnol. Adv. 2012; 27: 76- 83.

11. Birla, S.S., Tiwari, V.V., Gade, A.K., Ingle, A.P., Yadav, A.P., Rai, M.K. Fabrication of silver nanoparticles by Phoma glomerata and its combined effect against Escherichia coli, Pseudomonas aeruginosa and Staphylococcus aureus. Lett. Appl. Microbiol., 2009; 48: 173179.

12. Gade, A., Gaikwad, S., Tiwari, V., Yadav, A., Ingle, A., Rai, M. Biofabrication of silver nanoparticles by Opuntia ficus-indica: in vitro antibacterial activity and study of the mechanism involved in the synthesis. Curr Nanosci., 2010; 6: $370-375$.

13. Gajbhiye, M., Kesharwani, J., Ingle, A., Gade, A. and Rai, M. Fungus-mediated synthesis of silver nanoparticles and their activity against pathogenic fungi in combination with fluconazole. Nanomedicine., 2009: 5: 382-386.

14. Govindaraju, K., Tamilselvan, S., Kiruthiga, V. and Singaravelu, G. Biogenic silver nanoparticles by Solanum torvum and their promising antimicrobial activity antimicrobial activity of silver nanoparticles. J. Biopest., 2010: 3: 394 399.

15. Butkus, M.A., Labare, M.P., Starke, J.A., Moon, K. and Talbot, M. Use of aqueous silver to enhance inactivation of coliphage MS-2 by UV disinfection. Appl. Environ. Microbiol., 2004: 70: 2848-2853.

16. Brayner, R., Barberousse, H., Hemadi, M., Djedjat, C., Yepremian, C. Cyanobacteria as bioreactors for the synthesis of Au, Ag, Pd, and Pt nanoparticles via an enzyme-mediated route. Nanosci Nanotechnol., 2007; 7: 2696-2708.

17. Simon-Deckers, A,. Loo, S., Mayne-L’hermite, M., Herlin-Boime, N., Menguy, N., Reynaud, C., Gouget, B., Carrie re, M. Size, compositionand shape-dependent toxicological impact of metal oxide nanoparticles and carbon nanotubes toward bacteria. Environ Sci Technol., 2009; 43: 8423-8429.

18. Priester, J., Stoimenov, P., Mielke, R., Webb, S., Ehrhardt, C., Zhang, J., Stucky, G., Holden, P. Effects of soluble cadmium salts versus CdSe quantum dots on the growth of planktonic Pseudomonas aeruginosa. Environ Sci Technol., 2009; 43: 2589-2594.

19. Feng, Q.L., Wu, J., Chen, G.Q., Cui, F.Z., Kim, T.N., Kim, J.O. A mechanistic study of the antibacterial effect of silver ions on Escherichia coli and Staphylococcus aureus. J Biomed Mater Res., 2000; 52: 662-668.

20. Bar, H., Bhui, D.K., Sahoo, G.P., Sarkar, P., De, S.P., Misra, A. Colloids and Surfaces A: Physicochemical and Engineering Aspects., 2009; 339: 134-139.

21. Rodriguez-Sanchez, L., Blanco, M.C., LopezQuintela, M.A. Electrochemical synthesis of silver nanoparticles. J Phys Chem B., 2000; 104: 9683-9688.

22. Gericke, M., Pinches, A. Biological synthesis of metal nanoparticles. Hydrometallurgy. 2006; 83(1-4), 132-140.

23. Harris, A.T., Bali, R. On the formation and extent of uptake of silver nanoparticles by live plants. J. Nanopart. Res., 2008; 10: 691-695. 
24. Jha, A.K., Prasad, K., Kulkarni, A.R. Plant system: nature's nanofactory. Colloids Surf. B Biointerfaces. 2009; 73: 219-223.

25. Raja, S.K., Ganesh, S., Aviman, Y. “Evaluation of anti-bacterial activity of silver nanoparticles synthesized from Candida glabrata and Fusarium oxysporum," Int. J. Medicobiol. Res., 2011; 1(3): 130-136.

26. Das, B. et al., Green synthesized silver nanoparticles destroy multidrug resistant bacteria via reactive oxygen species mediated membrane damage. Arab. J. Chem., 2015; In Press doi:10.1016/j.arabjc.2015.08.008.

27. Nakkala, R., Mata, R. Gupta, A.K., Sadras, S.R. Green synthesis and characterization of silver nanoparticles using Boerhaavia diffusa plant extract and their antibacterial activity. Indus Crop Prod., 2014; 52: 562-566.

28. Banerjee, P., Satapathy, M., Mukhopahayay, A., Das, P. Leaf extract mediated green synthesis of silver nanoparticles from widely available Indian plants: synthesis, characterization, antimicrobial property and toxicity analysis. Biores. \& Bioprocess. 2014; 1: 3.

29. Ahmed, S., SIkram, S. Silver Nanoparticles: One Pot Green Synthesis Using Terminalia arjuna Extract for Biological Application. $J$ Nanomed Nanotechnol., 2015; 6: 309.

30. Krithiga, N., Athimoolam, R., and Ayyavoo, J., "Green Synthesis of Silver Nanoparticles Using Leaf Extracts of Clitoria ternatea and Solanum nigrum and Study of Its Antibacterial Effect against Common Nosocomial Pathogens," J. Nanosci., 2015; Article ID 928204, 8 pages.

31. Natarajan, K., Selvaraj, S., Murty, R.V. Microbial production of Silver nanoparticles. Dig $J$ Nanomater Biostruct., 2010; 1: 135-140.

32. Jaidev, L.R. and Narasimha, G. Fungal mediated biosynthesis of silver nanoparticles, Characterization and Antimicrobial activity. Colloids and surface B: Biointerfaces., 2010; 81: 430- 433.

33. Jannathul, M., Firdhouse, P., Lalitha, S., Sripathi, K. Novel synthesis of silver nanoparticles using leaf ethanol extract of Pisonia grandis (R. Br) Der Pharma Chemica. 2012; 4(6): 2320-2326.

34. Ganesan, V., Astalakshmi, A., Nima, P., Arunkumar, C. Synthesis and characterization of silver nanoparticles using Merremia tridentata (L.) Hall.f. Int. J. Curr. Sci., 2013a, 6: 87-93.

35. Ganesan, V., Aruna Devi, J., Astalakshmi, A., Nima, P., Thangaraja, A. Eco-friendly synthesis of silver nanoparticles using a sea weed, Kappaphycus alavarezii. Int. J. Eng. and Adv. Res. 2013b, (5): 559-563.
36. Satyavani, K., Gurudeeban, S., Ramanathan, T., Balasubramanian, T. Biomedical potential of silver nanoparticles synthesized from calli cells of Citrullus colocynthis (L.) Echrad. Asian J. Biotec. 2011; 9: 43.

37. Antariksh, S., Tripathi, R.M. Singh, R.P. Biological synthesis of silver nanoparticles using onion (Allium cepa) extract and their Antibacterial activity. Dig J Nanomater Biostruct., 2010; 5(2): 427-432.

38. Savithramma, N., Rao, M.L. Suvarnalatha Devi, P. Evaluation of Antibacterial efficacy of biologically synthesized silver nanoparticles using stem barks of Boswellia ovalifoliolata Bal. and Henry and Shorea tumbuggaia Ruxb. J. Biolog. Sci, 2011; 11: 39-45.

39. Jain, D., Daima, H.K., Kachnwaha, S., Kothari, S.L. Synthesis of plant mediated silver nanoparticles using Papaya fruit extract and evaluation of their antimicrobial activities. Dig $J$ Nanomater Biostruct.,2009, 4: 723-72

40. Ankamwar, B., Chaudhary, M., Sastry, M. Gold nanotriangles biologically synthesized using tamarind leaf extract and potential application in vapor sensing. Synth Reaction Inorg Metal Org Nanotech., 2005; 35(1): 19-26.

41. Elumalai, E.K., Prasad, T.N.V.K.V., Hemachandran, J., ViviyanTherasa, S., Thirumalai, T., David, E. Extracellular synthesis of silver nanoparticles using leaves of Euphorbia hirta and their antibacterial activities. J. Pharmac. Sci. and Res., 2010; 2(9): 549-554.

42. Prabhu, N., Divya, T.R. Yamuna, G. Synthesis of silver nanoparticles and their antibacterial efficacy. Dig J Nanomater Biostruct., 2010; 5: 185-189.

43. Pasupuleti, V.R., Prasad, T.N.V.K.V., Shiekh, R.A., Balam, S.K., Narasimhulu, G., Reddy, C.S., Rahman, I.A., Gan, S.H. Biogenic silver nanoparticles using Rhinacanthus nasutus leaf extract: synthesis, spectral analysis and antimicrobial studies. Int. J. Nanomed., 2013; 8: 3355-3364.

44. Lalitha, A., Subbaiya, Ponmurugan, P. Green synthesis of silver nanoparticles from leaf extract of Azadiractaindica and to study its antibacterial and antioxidant property. Int.J. Curr. Microbiol. Appl. Sci., 2013; 2(6): 228235.

45. Nalwade, A.R., Badhe, M.N., Pawale, C.B., Hinge, S.B. Rapid biosynthesis of silver nanoparticles using fern leaflet extract and evaluation of their antibacterial activity. Int. $J$. Biolog. Technol., 2013; 4(2): 12-18.

46. Beveridge, T.J., Fyfe, W.S. Metal fixation by bacterial cell walls. Can. J. Earth Sci., 1985; 
22:1893-1898.

47. Gogoi, S.K., Gopinath, P., Paul, A., Ramesh, A., Ghosh, S.S., Chattopadhyay, A. Green fluorescent protein-expressing Escherichia coli as a model system for investigating the antimicrobial activities of silver nanoparticles. Langmuir. 2006; 22: 22.

48. Danilcauk, M., Lund, A., Saldo, J., Yamada, H., Michalik, J. Conduction electron spin resonance of small silver particles. Spectrochimaca Acta Part A. 2006; 63:189-191. 